\title{
Partners not for life? on the determinants of marriage dissolution in Indonesia
}

\author{
Husni Vici Handalusia ${ }^{1}$, Nuryakin Chaikal ${ }^{1, *}$, and Massie Natanael Waraney Gerald ${ }^{1}$ \\ ${ }^{1}$ Economics Department, Faculty of Economics and Business, Universitas Indonesia, Kampus Baru \\ UI, Depok, Jawa Barat 16242, Indonesia
}

\begin{abstract}
While there have been numerous studies exploring the determinants of divorce in social science, economic studies on such marriage dissolution are scarce. Our study aims to examine the cause of divorce in Indonesia, exploring the socio-economic and demographic determinants including risk preference as to why couples choose whether to divorce or stay married. This study utilizes the data on married men and women from Indonesian Family Life Survey 2007 and 2014. In relation to husband-wife working composition, we find a very specific condition leading to marriage dissolution: when the wife is the only working, the main source of income of the family. The result indicates that there is a clash between the traditional family structures, especially a man as the househusband and the demographic change in the labor market for the sustainability of marriage. Furthermore, variables such as age, whether the marriage is the first marriage or not, and religiosity show considerable predictive validities.
\end{abstract}

\section{Introduction}

The causes of divorce, as one of the life phases for many, has been extensively discussed. Factors such as cohabitation [8], low educational level [10], and marriage secularization [6] are only a few of the long-standing list of related characteristics. Typical problems causing marriage dissolution have also widely explored, ranging from jealousy, drinking habit, and disagreements on money spending are generally noted [2]. This study aims to delve into the discussion. Specifically, we focus on Indonesia. Being one of the most multicultural countries globally, there is arguably a host of differences married couples in the country face.

We are interested in disentangling which factors act as the main determinants of divorce in the country by utilizing the rich, comprehensive datasets of Indonesian Family Life Survey (IFLS). Such usage enables a wide range of variables to be accounted for, including distinct, micro-level factors rarely attainable in other surveys of such size, e.g., religiosity, working nature of the couple and risk preferences. Consequently, there will be several contributions setting this study apart from its predecessors. The country we are using as a sample boasts one of the most diverse heritages in the region, if not the world. Furthermore,

\footnotetext{
* Corresponding author: chaikall@gmail.com
} 
the country is also renowned for the strong influence of religion in society. Gaining insights on which factors are the most predictive would contribute considerably into the discussion.

In Indonesia, the marital institution is rather conventional. The society is expected to have traditional, monogamous marriages of a husband and a wife and husband as the breadwinner of the family. Amid the contemporary shifts on the society's perspectives, however, there are several noteworthy aspects leading to the relevance of this study. First, the husband's roles are notably changing globally, one which is the male breadwinner model $[9,14,24]$ that has been on the decline or even the rise of househusband. As there is the inevitable rise of working women, the institution in Indonesia may have been illprepared in embracing the change. While further studies are needed to confirm any relationships, statistics suggest that during the period 2010-2014, the majority of the divorce cases are filed by women, peaking at a 70 percent level in 2014 [17]. We aim to delve deeper into such discussion in this study.

There are several notable findings we gathered in this study. First, we find that families in which the wife is the only working, the main income source are almost four times more likely to experience marriage dissolution. Such result stands despite dummies of women being the main earner of income and families with only either spouse working being not significant, indicating that only those above, specific set of couples is the more susceptible. We also find that the age of the couples and their religiosity affect the marriage dissolution decision. Another aspect such as whether the marriage is the first marriage or not is also shown to be a significant predictor on the matter. More findings shall be discussed more thoroughly within the body of the text.

The importance of such findings is not to be understated. We argue that while the results may seem trivial in a society such as Indonesia's, the results contribute to the understanding of the social construct facing the contemporary labor market dynamics. In fact, gender equality is highlighted in one of the seventeen sustainable development goals (SDGs). As countries across the globe are striving towards realizing such goals, our results may suggest that Indonesia is, to some extent, ill-prepared to embrace the sustained contribution of more working women.

In general, our study aims to investigate the determinants of divorce in Indonesia, along with the reasons as to why they matter socio-economically. It is broken into five parts. The first and ongoing part discusses the background of the study. Second, we provide the literature review of similar, previously conducted studies. The third section covers the methodologies used in the study. We present the results and discussions in the fourth, while the fifth section concludes.

\section{Literature review}

One of the first studies on the determinants of a person's decision to divorce is done by [4]. [4] argue that the gain of the marriage may be high enough to deter marriage dissolution if a person is married to his/her optimal partner. While the notion was simple, the study sparked numerous other researches investigating the phenomenon economically. [3] reviewed several cultural factors explaining divorce in Canada and other western countries in the second part of the $20^{\text {th }}$ century. Secularization and liberalization of norms, along with the lessening of religious influence are touted as several trends affecting the contemporary institution of marriage, leading to the general increase of divorce rate in the $19^{\text {th }}$ century [6]. [3] also argues that the passage of more liberal divorce laws helps normalizing divorce in the society.

The study, along with other researches, also discussed the demographic factors with considerable predictive validity. Age at marriage $[3,5,18,19]$, low educational levels $[8$, 
10], remarriages [7, 12], parental divorce [26], and religiosity [1, 8, 15, 22, 25], have been thoroughly discussed, among other factors.

A study by [13] replaced the assumption of risk-neutral agents with such that the agents are risk-averse by classifying marriage as a certain investment while marriage dissolution is an uncertain investment. Inevitably, the study found risk preferences to affect divorce decisions, in line with other similar, more recent studies [16, 21, 23]. The factors mentioned above are also explored in this study using the Indonesian data, conditional on the variables' availability in the datasets.

Similar studies have been rarely done with Indonesia as the main context. A couple of studies have explored the factors of divorce in Indonesia, albeit low in number. Research conducted by [20] using a sample of people residing in Java found that educational factors and age at marriage affect the probability of divorce. Also, research conducted by [11] using a sample of people who live in West Java suggested that one of the factors that affect divorce in Indonesia is ethnicity. These studies have disadvantages as they only take samples of certain areas in Indonesia and do not consider factors related to the economic theory such as the demographic factors and marriage characteristics. This study attempts to contribute by using the richer, more comprehensive data of the Indonesia Family Life Survey (IFLS), with details described in the following sections.

\section{Methodology}

This study was using data from the fourth wave of the Indonesian Family Life Survey (IFLS-4) in 2007 and IFLS-5 in 2014. IFLS data is a data sample of 30,000 people or about $83 \%$ of the total population in Indonesia. The sample was taken from 13 provinces in Indonesia, namely North Sumatra, West Sumatera, South Sumatera, Lampung, DKI Jakarta, West Java, Central Java, D.I. Yogyakarta, East Java, Bali, West Nusa Tenggara, South Kalimantan, and South Sulawesi.

We use sample who have been married in 2007 (in IFLS-4) and did not do polygamy as the assumptions used by [4]. Married status taken is legally married according to civil registration or religious law and adat law, while those who only live together exclude from the sample. The sample of divorce was taken from people who have at least one year of marriage is divorced between 2008 and 2014. The divorce sample is taken from people who separated and divorced, while the widower is excluded from the sample. Samples that have not been divorced are taken from people who did not change the status of marriage (not changing husband/wife) and not divorced until 2014. The divorce samples are then matched to the sample [4] that has not been divorced by the age of the respondent and their duration of marriage (every 10-years of marriage duration).

\subsection{Estimation method}

The estimation method used in this study is following the estimation model from [4] and [16] that is defined as follows:

$$
S_{\mathrm{i}}=E_{\mathrm{D}} U\left(D_{\mathrm{i}}\right)-E_{\mathrm{M}} U\left(M_{\mathrm{i}}\right)
$$

$S_{\mathrm{i}}$ is a factor that determines the "gain to marriage and divorce" of the individual i. If the couple is divorced, then $S_{\mathrm{i}}$ will be positive (or $E_{\mathrm{D}} U\left(D_{\mathrm{i}}\right)>E_{\mathrm{M}} U\left(M_{\mathrm{i}}\right)$ ) or gain to marriage will be positive if the value of expected utility to divorce exceeds the value of expected utility to marriage. On the other hand, if the couple is still marriage, $S_{\mathrm{i}}$ will be negative $\left(S_{\mathrm{i}}<\right.$ 0 ). We will calculate the probability of divorce or probability $S_{\mathrm{i}}>0$ by using Maximum Likelihood Estimation (MLE) with logit estimation. 
We define:

$$
\begin{aligned}
& Y_{\mathrm{i}}=1 \text { if } S_{\mathrm{i}}>0 \\
& Y_{\mathrm{i}}=0 \text { if } S_{\mathrm{i}}<0
\end{aligned}
$$

We then set the empirical model of this study as follows:

$$
Y_{\mathrm{i}}=1 /\left(1+\mathrm{e}^{-(B \mathrm{i} Q \mathrm{i}+u \mathrm{i})}\right)
$$

$Q \mathrm{i}$ is the variable vector that contains working status, age at marriage, marriage age, couples age difference, education, spouse's education, number of children, religiosity, ethnicity, gender, the dummy of the first marriage, risk preferences, or more $[4,13,16]$. Another control variable is the dummy of decision making within the household [2].

\section{Results and discussion}

To observe the determinants of marriage dissolution mentioned earlier, we used the logit regression method. The results of the estimation presented in the following table:

Table 1. Estimation results (odds ratio), processed from IFLS-4 and IFLS-5 data.

\begin{tabular}{l|r}
\hline \multicolumn{1}{c}{ Dependent variable: Divorce decision } & \multicolumn{1}{c}{$\begin{array}{c}\text { Odds } \\
\text { Ratio }\end{array}$} \\
\hline Age of respondent & $\mathbf{0 . 8 7 2 * * *}$ \\
Age at marriage & $\mathbf{1 . 1 2 5 * * *}$ \\
The age gap between spouse $\square$ & 1.031 \\
Respondents' years of education & 1.024 \\
Schooling gap between spouse & 0.978 \\
Number of children & 1.101 \\
Total family income (in Rupiah) & $\mathbf{1 . 0 0 0 * *}$ \\
Wife earning more income & 1.288 \\
Only one of the spouses working & 1.005 \\
Wife earning more income $x$ Only one of & \\
the spouses working (Interaction) & $\mathbf{4 . 0 7 3 * *}$ \\
First marriage & $\mathbf{0 . 0 4 0 * * *}$ \\
Risk preferences (ARA) & \\
Religiosity & 1.802 \\
$\quad$ Not religious & \\
Somewhat religious & \\
Religious & \\
Very religious & $\mathbf{0 . 4 1 4 * *}$ \\
Tribe & $\mathbf{0 . 4 3 9 * *}$ \\
Others & 0.743 \\
Java & \\
Sunda & \\
Minang & \\
Bali & 0.979 \\
Basak & 1.123 \\
\hline
\end{tabular}




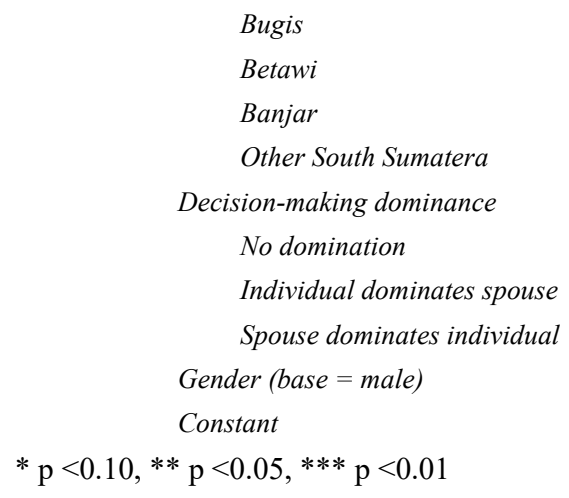

\section{Bugis}

Banjar

Other South Sumatera

ecision-making dominance

No domination

Individual dominates spouse

Spouse dominates individual

$=$ male

$$
* \mathrm{p}<0.10, * * \mathrm{p}<0.05, * * * \mathrm{p}<0.01
$$

In the above results, there are several interesting inferences observable. Our main finding, as mentioned earlier, is that families in which the wife is the only working, source of income are shown to be around four times more susceptible to marriage dissolution. The significance is rather intriguing, as neither dummies of whether the wife earns more income nor only one of the spouses works are significant. Such combination suggests that, interestingly, women earning more income than men in the family is, in fact, a somewhat acceptable situation and does not lead to higher chances of divorce. However, when such high-earning women are the sole source of income of the family, the divorce likelihood quadrupled. Our results may indicate what we describe as a clash between the traditional family structures, i.e., men as the breadwinner and the demographic change in the labor market. The findings provide empirical grounds on the theory by [4].

Age of the spouses and age of marriage are also shown to be significant predictors. The older the partners, marriage dissolution becomes less likely, consistent with $[4,16]$. Partners who marry later compared to others are also more prone to divorce. This finding might be explained by the possibility that in Indonesia, partners who marry later are somewhat less driven by affection, but rather by the peer pressure. Such, to some extent, forced consolidation may thus lead to a higher chance of divorce.

Furthermore, we also find that marriage dissolution is relatively less likely to happen in first marriages, consistent with [4]. Second marriages and more, however, are highly prone to divorce. This result might suggest the possible lack of chemistry in second marriages and more, thus leading to likelier marriage dissolution.

Religiosity is also strongly related to the chances of marriage dissolution. Compared to the relatively less religious, more religious partners generally show a smaller tendency towards divorce, providing further results similar to [11]. Comparing the two extremes, however, an interesting sight is noticeable. It appears that the least religious and the most religious partners are roughly similar in the chances of divorce, as there is no significant difference in our estimations. This finding might be elaborated, however, by one of the previously-mentioned relationships. We discussed above that second marriage and more lead to higher chances of marriage dissolution. One of the possible explanations of such similarity between the extremes is the fact that polygamy happens mostly in the more religious subset of partners of the majority religion in the country.

Several other variables which we originally hypothesized to have considerable relationships with the divorce decisions showed the otherwise. No apparent relationship is shown between the marriage dissolution decision and spouses' age gap, education level and gaps, number of children, and domestic decision-making dominance. Our findings thus provide evidence that as for the Indonesian case, such aspects might matter less compared to the relationships mentioned above. 
While the findings we observed above are firmly reflecting the common social construct in the country, we argue that such a phenomenon may not be taken lightly. As the global labor dynamics are shifting, the one in Indonesia is not exempted from such effects. The government may want to focus on efforts of normalizing such rise of working women in the society. As the number of such women in the labor market is not decreasing any time soon, certain cultural campaigns might prove to be one of the possible recommendations to help tackle the potential problems arising from the current situation.

\section{Conclusion}

Marriage dissolution might never be an easy decision for troubled couples. However, studies on its determinants have been widely explored. Our study has also attempted to shed more light on the determinants of divorce, specifically in Indonesia. We found that several important aspects are indeed significantly affecting the marriage dissolution decisions, such as the age at marriage and religiosity. Our main contribution to the literature, however, is arguably the evidence that a very specific type of wife-husband working composition is more prone to marriage dissolution, i.e., the composition in which only the wife works and earning most of the income for the family.

We want to highlight that the finding is timely if we consider the changing landscape of labor market demographic and domestic labor market decision-making. As more women works, families in the country - originally touted as conventional in a marital institution might be affected. Further researches are inevitably needed to confirm and extend the analysis conducted in the study. We acknowledge that as our study focuses on the couples in which at least one of the spouses works, more light may be shed if the sample is extended into Indonesian families in general. In concluding, however, we argue that our study may lead to certain implications. Notably, the country might need to readjust and, if possible, be less ill-prepared in facing the fact that more women work in modern society.

\section{References}

1. A. Adamczyk, EA 43, 1 (2013)

2. P.R. Amato, S.J. Rogers, J. of Marr and the Fam. 612-624 (1997)

3. A.M. Ambert, Divorce: Facts, causes, and consequences (2009)

4. G.S. Becker, E.M. Landes, R.T. Michael, J. of Pol. Econ. 85, 6, 1141-1187 (1977)

5. A. Booth, D.R. Johnson, L.K. White, J.N. Edwards, J. of Fam. Iss. 6, 3, 331-346 (1985)

6. A.J. Cherlin, J. of Marr and Fam. 66, 4, 848-861 (2004)

7. P.A. Chiappori, Y. Weiss, J. of Lab. Econ. 25, 1, 37-74 (2007)

8. W. Clark, S. Crompton, Statistics Canada Catalogue, 23-33 (2006)

9. C. Gather, L. Schürmann, H. Zipprian, Int. J. of Gen. and Entre. 8, 4, 353-372 (2016)

10. J. Greenwood, N. Guner, G. Kocharkov, C. Santos, AEJ: Macro. 8, 1, 1-41 (2016)

11. G. W. Jones, Y. Asari, T. Djuartika, J. of Comp. Fam. Stud. 25, 3, 395-416 (1994)

12. H. Juby, C. Le Bourdais, N. Marcil- Gratton, J. of Marr. and Fam. 67, 1, 157-172 (2005)

13. J.P. Leigh, App. Econ. 17, 2, 309-320 (1985)

14. J. Lewis, Soc. Pol.: Int. Stud. in Gen., St. \& Soc. 8, 2, 152-169 (2001)

15. S. Li, L. Kubzansky, T. VanderWeele, SSRN (2016) 
16. A. Light, T. Ahn, Dem. 47, 4, 895-921 (2010)

17. Indonesia Ministry of Religious Affairs, Ketika Perempuan Bersikap: Tren Cerai Gugat Masyarakat Muslim. Kementerian Agama Indonesia (2016)

18. A. Kuperberg, J. of Marr. and Fam. 76, 2, 352-369 (2014)

19. D. Rotz, J. of Hum. Res. 51, 4, 961-1002 (2016)

20. R. Savitridina, AP Pop J. 12, 2, 25-48 (1997)

21. L. Schmidt, Dem. 45, 2, 439-460 (2008)

22. J.R. Shimkowski, N. Punyanunt-Carter, M.J. Colwell, M.S. Norman, J. of Div. and Rem. 59, 3, 222-236 (2018)

23. C. Spivey, Econ. Inq. 48, 2, 499-516 (2010)

24. H. Trappe, M. Pollmann-Schult, C. Schmitt, Eur. Socio. Rev. 31, 2, 230-242 (2015)

25. J. Treas, D. Giesen, J. of Marr. and Fam. 62, 1, 48-60 (2000)

26. S.W. Whitton, G.K. Rhoades, S.M. Stanley, H.J. Markman, J. of Fam. Psy. 22, 5, 789 (2008) 